\title{
Lymphatic Mapping and Sentinel Lymph Node Biopsy for Breast Cancer Patients
}

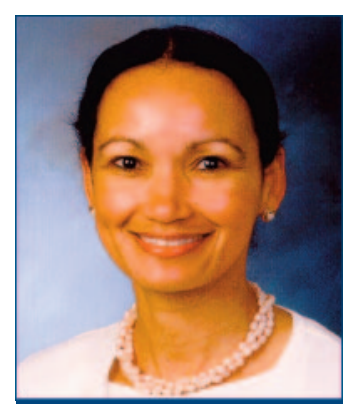

Lisa A. Newman, $M D$ MPH, FACS
By Lisa A. Newman, $M D$, $M P H$, FACS

The ASCO Health Services and Technology Committee has done an excellent job of providing a comprehensive review of the available evidence to date regarding lymphatic mapping and sentinel lymph node biopsy in breast cancer patients. The executive summary of their review is published in this issue of the

Journal of Oncology Practice ("ASCO Guideline

Recommendations for Sentinel Lymph Node Biopsy in EarlyStage Breast Cancer: Guideline Summary," p. 166). Lyman et al are to be congratulated for their extensive analyses. My commentary will address progress related to the selection of patients and the performance of lymphatic mapping in breast cancer patients.

\section{Utilization of the Lymphatic Mapping Technology: Who Is Performing Sentinel Lymph Node Biopsy for Breast Cancer Patients?}

Enthusiasm for reducing the number of breast cancer patients who must face the potential morbidity of a standard axillary lymph node dissection (lymphedema, sensory loss, shoulder dysfunction, and others) has motivated a brisk increase in interest for lymphatic mapping and sentinel lymph node dissection (SLND) since the initial reports were published by Giuliano et $\mathrm{al}^{1}$ and Krag et $\mathrm{al}^{2}$ more than 10 years ago.

Lymphatic mapping requires the coordinated efforts of several disciplines (surgery, nuclear medicine, breast imaging, and pathology) in order to ensure its smooth integration into the daily surgical schedule. Establishment of a lymphatic mapping program requires an infrastructure that accommodates innovative interdisciplinary work, and it also requires a financial investment for the intraoperative equipment and training of the surgical staff. It was, therefore, predictable that relatively more affluent medical facilities, such as the comprehensive cancer centers and university hospitals, would be the leaders in embracing this technology. The pace at which cancer centers adopted SLND was documented nicely by Edge et $\mathrm{al}^{3}$ in their review of more than 3,000 early-stage breast cancer patients treated at the five original participants of the National Comprehensive Cancer Network (NCCN) between 1997 and 2000. During this time frame, the proportion of stage I breast conservation therapy patients undergoing SLND as the only axillary staging procedure increased from $8 \%$ to $58 \%$.

Lucci at al ${ }^{4}$ surveyed 1,000 randomly selected Fellows from the American College of Surgeons regarding their utilization of lymphatic mapping and SLND, and of the 410 respondents, $77 \%$ reported that they had incorporated this technology into their care of breast cancer patients. One quarter of these respondents had learned about lymphatic mapping through fellowship training, and $51 \%$ had full-time academic practices, indicating that these results represent practice patterns for a relatively highly selected subset of physicians with specialized surgical oncology training.

In contrast to the rapid increase in popularity for SLND among selected centers, evidence of its limited availability for the general population was provided by Maggard et $\mathrm{al}^{5}$ in an analysis of data from the Surveillance, Epidemiology, and End Results (SEER) Program for early-stage breast cancer patients treated between 1998 and 2000. Although SLND rates increased from $13.5 \%$ of cases in 1998 to $36.4 \%$ in 2000 , there were notable disparities in demographics for the patient populations that had access to this technology.

Lymphatic mapping rates were relatively higher on the East and West Coasts (22\% to 33\%) compared with Alaska, Iowa, and Utah ( $8 \%$ to $18 \%)$. Minority-ethnicity patients (African Americans, Hispanic Americans, and Asian Americans) were also significantly less likely to undergo lymphatic mapping and SLND compared with white American breast cancer patients.

\section{Utilization of the Lymphatic Mapping Technology: Who Should (or shouldn't) Be Performing Sentinel Lymph Node Biopsy for Breast Cancer Patients?}

An appreciation for the learning curve associated with safe and accurate performance of lymphatic mapping and SLND was noted in several of the earliest reports regarding its implementation. These pioneer studies of SLND involved sentinel lymph node biopsy performed in conjunction with the standard axillary lymph node dissection (ALND) so that the sentinel node accuracy could be quantified. In their landmark 1994 study of lymphatic mapping attempted in 174 patients, Giuliano et al $^{1}$ reported a sentinel lymph node identification rate of $65 \%$ overall; however, falsely negative sentinel nodes occurred only in the earliest cases. The procedure was associated with $100 \%$ accuracy for cases performed in the second half of the study.

Although it is important to demonstrate that the sentinel lymph node can be found (by quantifying the identification 
Table 1. Studies reporting long-term follow-up results for patients undergoing resection of a negative sentinel node and no completion axillary lymph node dissection

\begin{tabular}{|c|c|c|c|c|c|c|c|c|c|}
\hline \multirow[t]{2}{*}{ Study } & \multirow[t]{2}{*}{ Year } & \multirow[t]{2}{*}{$\begin{array}{l}\text { No. of } \\
\text { Cases }\end{array}$} & \multirow[t]{2}{*}{$\begin{array}{l}\text { Diagnosis } \\
\text { Interval }\end{array}$} & \multirow[t]{2}{*}{$\begin{array}{l}\text { Stage } \\
\text { Distribution }\end{array}$} & \multirow[t]{2}{*}{ Follow-Up } & \multicolumn{2}{|c|}{$\begin{array}{l}\text { Axillary } \\
\text { Failures }\end{array}$} & \multirow{2}{*}{$\begin{array}{l}\text { Time to } \\
\text { Failure } \\
\text { (months) }\end{array}$} & \multirow{2}{*}{$\begin{array}{l}\text { Stage of } \\
\text { Breast } \\
\text { Primary }\end{array}$} \\
\hline & & & & & & No. & $\%$ & & \\
\hline Blanchard $^{14}$ & 2003 & 685 & $1997-2001$ & $\mathrm{~T} 1, \mathrm{~T} 2$ & $\begin{array}{l}2.4 \text { years } \\
\text { (mean) }\end{array}$ & 1 & 0.1 & 41 & NR \\
\hline Naik $^{15}$ & 2004 & 2,340 & 1996-2003 & T1-T3 & $\begin{array}{l}31 \text { months } \\
\text { (median) }\end{array}$ & 3 & 0.12 & $\begin{array}{l}18.5 \\
28.9 \\
32.9\end{array}$ & $\begin{array}{l}\text { T1b } \\
\text { T1b } \\
\text { T1b }\end{array}$ \\
\hline Giuliano $^{16}$ & 2000 & 67 & 1995-1997 & $\leq 4 \mathrm{~cm}$ & $\begin{array}{l}39 \text { months } \\
\text { (median) }\end{array}$ & \multicolumn{2}{|c|}{0} & \multicolumn{2}{|c|}{ NA } \\
\hline Veronesi ${ }^{17}$ & 2005 & 953 & $1996-2000$ & $\mathrm{~T} 1$ & $\begin{array}{l}38 \text { months } \\
\text { (median) }\end{array}$ & 3 & 0.3 & $\begin{array}{l}26 \\
29 \\
37\end{array}$ & $\begin{array}{l}\text { T1c } \\
\text { T2 } \\
\text { T1c }\end{array}$ \\
\hline Roumen $^{18}$ & 2001 & 100 & $1997-2000$ & $\mathrm{~T} 1, \mathrm{~T} 2$ & $\begin{array}{l}24 \text { months } \\
\text { (median) }\end{array}$ & 1 & 1 & 14 & $\mathrm{~T} 1 \mathrm{~b}$ \\
\hline Reitsamer $^{19}$ & 2004 & 200 & 1999-2002 & $\leq 4 \mathrm{~cm}$ & $\begin{array}{l}36 \text { months } \\
\text { (median) }\end{array}$ & \multicolumn{2}{|c|}{0} & \multicolumn{2}{|c|}{ NA } \\
\hline Jeruss $^{20}$ & 2005 & 592 & 1996-2003 & T1-T4 & $\begin{array}{l}27.4 \text { months } \\
\text { (median) }\end{array}$ & 1 & 0.16 & 22 & $\mathrm{~T} 2$ \\
\hline Chung ${ }^{21}$ & 2002 & 206 & $1998-2001$ & $<3 \mathrm{~cm}$ & $\begin{array}{l}26 \text { months } \\
\text { (median) }\end{array}$ & 3 & 1.4 & $\begin{array}{r}4 \\
11 \\
31\end{array}$ & $\begin{array}{l}\text { T1c } \\
\text { T1c } \\
\text { T1a }\end{array}$ \\
\hline Smidt ${ }^{22}$ & 2005 & 439 & $1998-2003$ & $\mathrm{~T} 1, \mathrm{~T} 2$ & $\begin{array}{l}26 \text { months } \\
\text { (median) }\end{array}$ & 2 & 0.5 & $\begin{array}{r}4 \\
27\end{array}$ & $\begin{array}{l}\mathrm{T} 2 \\
\mathrm{~T} 1 \mathrm{c}\end{array}$ \\
\hline $\operatorname{Fan}^{23}$ & 2005 & 237 & $1997-2002$ & T1-T3 & $\begin{array}{l}31.1 \text { months } \\
\text { (median) }\end{array}$ & 2 & 1 & $\begin{array}{r}4.9 \\
17.9\end{array}$ & $\begin{array}{l}\text { NR } \\
\text { NR }\end{array}$ \\
\hline
\end{tabular}

Abbreviation: NR, not reported.

rate), calculation of the false-negative rate is the key element to be defined before the procedure can be relied upon as a stand-alone means of staging the axilla. Estimate of the falsenegative rate (number of metastatic sentinel nodes relative to the number of axillae with metastases in sentinel nodes and/or nonsentinel nodes) requires that the surgeon attempt the procedure in a reasonable volume of breast cancer patients, and that a "meaningful" proportion of these patients have nodepositive breast cancer. For example, finding a negative sentinel lymph node in 50 node-negative patients yields a 100\% identification rate, but tells nothing about the negative predictive value of the technology for that particular surgical practice.

There is no external credentialing body for the surgical practice of SLND, and accordingly there are no uniform standards for the total number of cases, nor the total number of node-positive cases that a surgeon should perform before he/she is qualified to perform SLND without a concomitant ALND. Furthermore, additional variation in success with the technology will be introduced on the basis of individual surgical skill, and the frequency of lymphatic mapping. As noted by Giuliano et al ${ }^{6}{ }^{6}$ ox et al, ${ }^{7}$ and Krag et al, ${ }^{8}$ adequate expertise with SLND may be obtained with markedly different case volumes for individual surgeons, and even among experienced surgeons, false-negative rates can range from $0 \%$ to $30 \%$. The generally accepted threshold for achieving "acceptable" skill seems to average at 20 to 40 cases. ${ }^{6,7,9}$ For the cooperative groups (American College of Surgeons Oncology Group [ACOSOG]; National Surgical Adjuvant Breast Project [NSABP]; and the ALMANAC [Lymphatic Mapping Against Nodal Clearance] trialists), skills verification with lymphatic mapping for participating surgeons was documented by the performance of 30 to 40 "qualifying cases" demonstrating identification rates of at least $90 \%$ and false-negative rates of $\leq 5 \%$, or via monitored operative experience.

\section{Axillary Management After the Sentinel Lymph Node Biopsy}

In the Lyman et al review of worldwide experience with SLND, false-negative rates for SLND have settled at less than $10 \%$, and as an oncology community we have come to accept this level of accuracy in exchange for diminished treatmentrelated morbidity. Indeed, the cancer clinical trials cooperative groups are now reporting their long-term outcome results, and reduced rates of lymphedema and other upper extremity sequelae have been confirmed at 5 years of follow-up for SLND compared with ALND (NSABP, ALMANAC, ACOSOG). ${ }^{10-13}$ As shown in Table 1, 
Table 2. Follow-up of patients undergoing resection of a positive sentinel node and no completion ALND

\begin{tabular}{|c|c|c|c|c|c|c|c|c|c|}
\hline \multirow[t]{2}{*}{ Study } & \multirow[t]{2}{*}{ Year } & \multirow[t]{2}{*}{$\begin{array}{l}\text { No. of } \\
\text { Cases }\end{array}$} & \multirow[t]{2}{*}{$\begin{array}{l}\text { Diagnosis } \\
\text { Interval }\end{array}$} & \multirow[t]{2}{*}{$\begin{array}{l}\text { Stage } \\
\text { Distribution }\end{array}$} & \multirow[t]{2}{*}{$\begin{array}{l}\text { Follow-Up } \\
\text { (months) }\end{array}$} & \multicolumn{2}{|c|}{$\begin{array}{l}\text { Axillary } \\
\text { Failures }\end{array}$} & \multirow{2}{*}{$\begin{array}{l}\text { Time to } \\
\text { Failure } \\
\text { (months) }\end{array}$} & \multirow{2}{*}{$\begin{array}{l}\text { Size of } \\
\text { Breast } \\
\text { Primary }\end{array}$} \\
\hline & & & & & & No. & $\%$ & & \\
\hline Fant $^{27}$ & 2003 & 46 & 1998-2000 & $\mathrm{T} 1, \mathrm{~T} 2$ & 30 (mean) & \multicolumn{2}{|c|}{0} & \multicolumn{2}{|c|}{ NA } \\
\hline Naik $^{19}$ & 2004 & 210 & 1996-2001 & T1-T3 & $\begin{array}{l}25 \\
\text { (median) }\end{array}$ & 3 & 1.4 & $\begin{array}{l}10.7 \\
18.7 \\
46.0\end{array}$ & $\begin{array}{l}\mathrm{T} 1 \mathrm{c} \\
\mathrm{T} 1 \mathrm{c} \\
\mathrm{T} 2\end{array}$ \\
\hline Jeruss $^{20}$ & 2005 & 73 & 1996-2003 & T1-T4 & $\begin{array}{l}27.6 \\
\text { (mean) }\end{array}$ & \multicolumn{2}{|c|}{0} & \multicolumn{2}{|c|}{ NA } \\
\hline $\operatorname{Fan}^{23}$ & 2005 & 38 & 1997-2002 & T1-T3 & $\begin{array}{l}31.1 \\
\text { (median) }\end{array}$ & 1 & 2.6 & 16.9 & T2 \\
\hline
\end{tabular}

Abbreviation: NA, not applicable

numerous investigators are now also reporting their results after resection of a negative sentinel node performed without the back-up ALND; at an average follow-up of 3 years, the rates of axillary recurrence are gratifyingly low.

Appropriate management for the sentinel node-positive patient continues to be debated. Controversy regarding the optimal management of clinically node-negative, but pathologically node-positive, breast cancer patients dates back to the NSABP B-04 trial. ${ }^{24}$ This study (conducted in an era before widespread availability of effective systemic therapy for breast cancer) demonstrated equivalent overall survival at 25 years for early-stage breast cancer patients regardless of whether the axillae was surgically dissected, and $40 \%$ of the undissected axillae are presumed to have been pathologically node positive. Subsequent to the completion of B-04, we have relied upon extent of axillary disease as a valuable means of stratifying relapse risk. This information has guided recommendations for locoregional radiation and intensity of chemotherapy; furthermore, it remains possible that surgical extirpation of metastatic nodes may contribute to survival. The ACOSOG Z0011 trial, which randomly assigned sentinel node-positive patients to undergo completion ALND versus axillary observation (with systemic therapy dictated by the primary treating oncology team) was designed to address this question. Unfortunately this trial was closed to accrual because of inability to meet its accrual target, and we may never have a definitive answer. Hopefully, ongoing European trials will be successful in randomly assigning and following the sentinel node-positive breast cancer patients. ${ }^{25}$

A completion ALND, therefore, remains the standard of care management for patients who are found to be node positive on the basis of a sentinel lymph node biopsy. Uncertainty regarding this dogma, however, is evidenced by the numerous patients who are declining the additional axillary surgery. As shown in Table 2, several investigators have accumulated and reported their experience with patients who have undergone resection of metastatic sentinel nodes without the completion
ALND. Follow-up intervals are relatively short (2 to 3 years), but, thus far, axillary failures have been uncommon.

Nonetheless, this practice is far too immature to be adopted on a routine basis, and sentinel node-positive patients should continue to be advised that the ALND is the accepted standard. Preliminary data from the ALMANAC trial suggest that axillary irradiation may be a reasonable alternative for these patients in terms of protecting against regional failure, but this therapy appears to have lymphedema rates that are comparable to those of an ALND. ${ }^{28}$

\section{Conclusion}

Lymphatic mapping and sentinel lymph node biopsy are now well established in our armamentarium of breast cancer staging and treatment strategies. Although institutional- and individual surgeon-related learning curves clearly exist, there are no universal standards that define where or on whom the procedure should be performed. Expertise with the technology has increased rapidly in academic and affluent health care environments, and there has been a commensurate accumulation of evidence regarding its safety, accuracy, and low morbidity. Unfortunately however, disparities in its availability are also apparent. As is observed with many other aspects of health care, minority-ethnicity and geographically remote populations are disproportionately deprived of benefiting from this advance in oncology.

Lisa A. Newman, MZD, MPH, FACS, is an associate professor and surgery director at the Breast Care Center, University of Michigan, Ann Arbor, Michigan.

\section{References}

1. Giuliano AE, Kirgan DM, Guenther JM, et al: Lymphatic mapping and sentinel lymphadenectomy for breast cancer. Ann Surg 220:391401, 1994

2. Krag DN, Weaver DL, Alex JC, et al: Surgical resection and radiolocalization of the sentinel lymph node in breast cancer using a gamma probe. Surg Oncol 2:335-340, 1993

3. Edge SB, Niland JC, Bookman MA, et al: Emergence of sentinel node biopsy in breast cancer as standard-of-care in academic comprehensive cancer centers. J Natl Cancer Inst 95:1514-1521, 2003 
4. Lucci A Jr, Kelemen PR, Miller C III, et al: National practice patterns of sentinel lymph node dissection for breast carcinoma. J Am Coll Surg 192:453-458, 2001

5. Maggard MA, Lane KE, O'Connell JB, et al: Beyond the clinical trials: How often is sentinel lymph node dissection performed for breast cancer? Ann Surg Oncol 12:41-47, 2005

6. Giuliano AE: See one, do twenty-five, teach one: The implementation of sentinel node dissection in breast cancer. Ann Surg Oncol 6:520-521, 1999

7. Cox CE, Bass SS, Boulware D, et al: Implementation of new surgical technology: Outcome measures for lymphatic mapping of breast carcinoma. Ann Surg Oncol 6:553-561, 1999

8. Krag D, Weaver D, Ashikaga $T$, et al: The sentinel node in breast cancer: A multicenter validation study. N Engl J Med 339:941-946, 1998

9. Tafra L: The learning curve and sentinel node biopsy. Am J Surg 182:347-350, 2001

10. Julian $T$, Krag D, Brown A, et al: Preliminary technical results of NSABP B-32, a randomized phase III clinical trial to compare sentinel node resection to conventional axillary dissection in clinically nodenegative breast cancer patients. Presented at the San Antonio Breast Cancer Symposium, San Antonio, TX, December 8-11, 2004 (abstr 14)

11. Mansel R, Goyal A, Fallowfield L, et al: Sentinel node biopsy versus standard axillary treatment: Results of the randomized multicenter UK ALMANAC trial. Presented the San Antonio Breast Cancer Symposium, San Antonio, TX, December 8-11, 2004 (abstr 18)

12. Mansel R, Goyal A, Newcombe R, et al: Objective assessment of lymphedema, shoulder dysfunction and sensory deficit after sentinel node biopsy for invasive breast cancer: ALMANAC trial. Presented at the San Antonio Breast Cancer Symposium, San Antonio, TX, December 8-11, 2004 (abstr 15)

13. Wilke LG, Hunt K, Giuliano A: American College of Surgeons Oncology Group Z0010 trial: Early Results. Presented at the Society of Surgical Oncology Annual Cancer Symposium, Chicago, IL, March 3-6, 2005

14. Blanchard DK, Donohue JH, Reynolds C, et al: Relapse and morbidity in patients undergoing sentinel lymph node biopsy alone or with axillary dissection for breast cancer. Arch Surg 138:482-488, 2003

15. Naik AM, Fey J, Gemignani M, et al: The risk of axillary relapse after sentinel lymph node biopsy for breast cancer is comparable with that of axillary lymph node dissection: A follow-up study of 4008 procedures. Ann Surg 240:462-471, 2004
16. Giuliano AE, Haigh PI, Brennan MB, et al: Prospective observational study of sentinel lymphadenectomy without further axillary dissection in patients with sentinel node-negative breast cancer. J Clin Oncol 18:2553-2559, 2000

17. Veronesi U, Galimberti V, Mariani L, et al: Sentinel node biopsy in breast cancer: Early results in 953 patients with negative sentinel node biopsy and no axillary dissection. Eur J Cancer 41:231-237, 2005

19. Roumen RM, Kuijt GP, Liem IH, et al: Treatment of 100 patients with sentinel node-negative breast cancer without further axillary dissection. Br J Surg 88:1639-1643, 2001

19. Reitsamer R, Peintinger F, Prokop E, et al: 200 Sentinel lymph node biopsies without axillary lymph node dissection: No axillary recurrences after a 3-year follow-up. Br J Cancer 90:1551-1554, 2004

20. Jeruss JS, Winchester DJ, Sener SF, et al: Axillary recurrence after sentinel node biopsy. Ann Surg Oncol 12:34-40, 2005

21. Chung MA, Steinhoff MM, Cady B: Clinical axillary recurrence in breast cancer patients after a negative sentinel node biopsy. Am J Surg 184:310-314, 2002

22. Smidt ML, Janssen CM, Kuster DM, et al: Axillary recurrence after a negative sentinel node biopsy for breast cancer: Incidence and clinical significance. Ann Surg Oncol 12:29-33, 2005

23. Fan YG, Tan YY, Wu CT, et al: The effect of sentinel node tumor burden on non-sentinel node status and recurrence rates in breast cancer. Ann Surg Oncol 12:705-711, 2005

24. Fisher B, Jeong JH, Anderson S, et al: Twenty-five-year follow-up of a randomized trial comparing radical mastectomy, total mastectomy, and total mastectomy followed by irradiation. N Engl J Med 347:567-575, 2002

25. Mansel RE, Goyal A: European studies on lymphatic mapping. Semin Oncol 31:304-310, 2004

26. Guenther JM, Hansen NM, DiFronzo LA, et al: Axillary dissection is not required for all patients with breast cancer and positive sentinel nodes. Arch Surg 138:52-56, 2003

27. Fant JS, Grant MD, Knox SM, et al: Preliminary outcome analysis in patients with breast cancer and a positive sentinel lymph node who declined axillary dissection. Ann Surg Oncol 10:126-130, 2003

28. Goyal A, Newcombe R, Mansel R, et al: Axillary treatment in patients with positive sentinel nodes- Radiotherapy or dissection? Presented at the San Antonio Breast Cancer Symposium, San Antonio, TX, December 8-11, 2004 (abstr 1056) 